\title{
José María Balcells, Sujetado rayo, Estudios sobre Miguel Hernández, Madrid, Devenir, 2009, 249 pp.
}

En el transcurso de las efemérides literarias, como en el caso de este centenario hernandiano, se suceden las aportaciones de variado signo. Contribuciones biográficas, pequeños asomos a la peripecia mundana, aportes, en suma, de índole básicamente divulgativa y trabajos científicos, filológicos. A estos últimos pertenece Sujetado rayo, del catedrático don José María Balcells.

No se le niega, en absoluto, la validez científica al género biográfico, a lo que antaño decíase vida o noticia del autor, del poeta, en este caso. Si Miguel Hernández sigue tan vivo entre nosotros es, en buena parte, debido al impacto que su fulgurante existencia ha dejado en el imaginario colectivo español y, se puede afirmar sin errar, del de allende nuestras fronteras. Parece que la siguiente afirmación de Camilo José Cela, en 1977, tiene una vigencia absoluta: “Ningún muerto vive hoy con tanta vida -mortal e inmortal como Miguel Hernández.

Cualquier día de cualquier año es fecha precisa del poeta, como las piedras de Toledo lo son de Garcilaso, según el lapidario soneto de Góngora. Año tras año asistimos a la ascensión en gloria perenne y siempre creciente del poeta de Orihuela." Sin embargo, si queremos aquilatar la poesía de Miguel Hernández, aprehender su esencia, entrar en ella en definitiva, tendremos que separar el ruido del silencio, la algarabía sin sentido de la verdadera música callada de sus versos. Sin prescindir del Miguel Hernández hombre, hay que adentrarse en puridad en el Miguel Hernández poeta. Ésa es la antorcha de la verdadera filología, la que se conserva encendida más allá de la ambición meramente noticiera y militante. La que halla su fuego en el propio verso, la que persigue la verdad poética. En el discurso filológico verdadero sobre la poesía hernandiana, cabe la experiencia vital, pero desde el filtro inapelable de la ficción poética.

Quien quiera conocer a Miguel Hernández que siga la senda de sus versos. Que atienda al humanismo, más que al hombre. Quizá, así, descubra también al hombre. El fin último de todo arte pueda ser la vida, pero a través de ese filtro volátil, del arte. A través de la poesía, la vida y no al revés. Ése es el camino real de la poesía, de donde surge justamente el Sujetado rayo de Balcells. Como él mismo asevera: “(...) no procede que se asimilen biografía y creación poética, y hay que huir de tamaño despropósito." 
Es un libro necesario, a la luz de tales argumentos. Por muchos motivos, pero especialmente por uno, ineludible. Cualquier alumno aventajado o profesor o lector inquieto conoce, entre tantas otras, cuáles han sido las dos pasiones que han acompañado la existencia fructífera del maestro: Francisco de Quevedo, por un lado, y Miguel Hernández, por otro. Repetimos, entre tantas otras. El que ahora nos ocupa es Hernández, sin embargo. Junto a Juan Cano Ballesta, Chevallier, Ifach, Díez de Revenga, Concha Zardoya o Leopoldo de Luis, por citar algunos de los críticos más representativos, José María Balcells se sitúa desde los años setenta en lugar común, imprescindible, dentro de la interpretación filológica de la vida y la obra del poeta oriolano. Nos referimos a la publicación de su libro Miguel Hernández, corazón desmesurado. Desde entonces -en realidad, desde mucho antes-, Balcells ha indagado en la obra hernandiana, sujetado él mismo al rigor de la mejor filología. Éste es el primer motivo que cumple Sujetado rayo.

El libro está escrito, como toda la bibliografía de Balcells en torno a Miguel Hernández, desde la pasión contenida y sabiamente encauzada por los cánones de la ciencia literaria, si es que convenimos en denominar así al noble arte de la filología. Conlleva una dificultad considerable, para un crítico, indagar en aquello que se ama, que sabemos apreciar desde lo más profundo. He aquí el caso. Certificamos desde aquí que Balcells ha podido cumplir su voluntad juvenil, manifestada en el prólogo a Miguel Hernández, corazón desmesurado: “(...) nosotros quisiéramos que Miguel Hernández no hubiera sido apresado de nuevo entre los renglones de este recorrido por su vida y por su obra (...) Nosotros quisiéramos que Miguel -o los ojos de agua de su rostro terrícola- nos sorprendiera redoblándonos muy penetrante su palabra, que todavía nos propone soñar caminos en la tarde..."La riqueza de la obra hernandiana ha permitido que todavía hoy la crítica pueda seguir echando luz sobre aspectos cruciales del poeta. Es decir, Miguel Hernández ha devenido en un clásico de la poesía española, del que distamos mucho de haber escrito la última palabra. Y Sujetado rayo es la evidencia de este axioma.

La poesía hernandiana goza de un interés constante, sin menoscabo del paso del tiempo. Libros como Sujetado rayo ayudan a reencontrarse con el poeta, desde el punto de vista crítico y filológico. La estructura del libro está construida a partir de diferentes trabajos, dedicados por Balcells a Miguel Hernández. Como afirma el propio autor en el prólogo: “La conmemoración del primer centenario del nacimiento de Miguel Hernández ha de ser motivo para el logro de un nuevo impulso en la lectura del poeta, y en la investigación sobre su obra y su vida. Con vista a este fin resulta conveniente también el rescate de estudios científicos, no siempre de fácil acceso y dispersos, que puedan ser útiles para las tareas de quienes vayan a emprender nuevas contribuciones al hernandismo. 
Y este libro se inscribe en esta dirección." En total, son ocho trabajos sobre la obra y la vida hernandiana, con los que Balcells recorre no sólo la trayectoria poética de Miguel Hernández, sino también la suya propia como crítico. Los textos están agrupados bajo los siguientes epígrafes: 1. La prehistoria poética; 2. Las huellas de Rubén Darío; 3. Los estímulos de Quevedo; 4. Gestación y lenguaje poético en El rayo que no cesa; 5. El rayo que no cesa desde la intertextualidad; 6. La sátira de guerra; 7. El trabajo: una perspectiva poética. Y el resultado es deslumbrante, a causa de la calidad de los trabajos y del estilo brillante de Balcells. Ciencia y estilo se fusionan a lo largo de los diferentes artículos y trabajos.

El primero de ellos es "La prehistoria poética de Miguel Hernández". Cuánta importancia tiene el estadio poético previo al de la consagración de una voz poética, eso lo podemos apreciar a lo largo de este interesante estudio. La motivación del mismo radica en la labor editorial que Agustín Sánchez Vidal y José Carlos Rovira realizaron en 1992 con la publicación de la Obra completa de Miguel Hernández. Dicha labor, heredera de las que en su día ya dieron a imprenta, en sus respectivas ediciones de la obra hernandiana, críticos como Francisco Marín, Claude Couffon o Leopoldo de Luis y Jorge Urrutia, se unifica en la mencionada edición crítica. Su esfuerzo editorial y filológico ofreció a los críticos un material inédito considerable. Dicho material insta a Balcells a un análisis del mismo, desde la perspectiva del experto hernandiano. $\mathrm{Y}$ aunque el propio autor reconoce que "un nuevo acercamiento a las poesías más tempranas de Miguel Hernández difícilmente puede aportar consideraciones fundamentales para la mejor comprensión de su obra poética", sin embargo, el trabajo es del todo revelador de la fase inicial de su trayectoria poética. El lector asiste a una labor minuciosa y certera de aquilatamiento de fuentes y débitos de la poesía hernandiana en sus comienzos. El desapego del localismo, las reminiscencias románticas (Bécquer, Espronceda, Heine) y modernistas ( Rubén Darío, Antonio Machado, Gabriel Miró), son ecos que pueblan los primeros poemas del vate oriolano. Rastrearlos y situarlos en su dimensión correcta es la aportación máxima de esta "prehistoria".

En "Las huellas de Rubén Darío", capítulo siguiente a "La prehistoria”, Balcells abunda en los orígenes poéticos, formativos. La literatura modernista influyó profundamente en la poesía española del siglo xx y el poeta alicantino no sería una excepción. Bien al contrario, en palabras de Balcells, "uno de los lenguajes literarios fundamentales de la prehistoria hernandiana fue el modernista, lenguaje que en gran medida se debió a lecturas, imitaciones y reminiscencias de Rubén Darío (...)". De enorme interés es la consideración de los metros adoptados por Miguel Hernández en sus inicios. La influencia del nicaragüense se hace patente a través de tipos versales como el alejandrino y el dodecasílabo. No en vano se ha considerado la figura del oriolano como un -sería más certero "él"- epígono de la poesía del 27. Como Vicente Aleixandre, Hernández encontró en la poesía rubeniana cauces métricos y expresivos, 
que le permitieron dar forma a su voz poética. Rubén Darío estuvo muy presente en ambos poetas. No es una casualidad. C.B. Morris -en Una generación de poetas españoles (1920-1936)definía la influencia de Rubén Darío sobre las letras españolas como "vigorosa revitalización". Juan Cano Ballesta, Díez de Revenga, Martínez Marín se han ocupado de los débitos modernistas del nicaragüense en la poesía de Miguel Hernández. En esta línea va este capítulo de Balcells, aportando, si cabe, nuevas perspectivas de estudio.

Y en consonancia con "Las huellas de Rubén Darío", se sitúa "Los estímulos de Quevedo". Se trata de uno de los trabajos más interesantes de Sujetado rayo. Más bien se trata de un privilegio para el lector. En este capítulo se cruzan dos ríos de conocimiento, el de Miguel Hernández y el de Francisco de Quevedo. Si el rastreo de las influencias rubenianas aportaba claves para conocer los orígenes del poeta, con el aquilatamiento de la impronta quevedesca podemos reconocer la identificación entre el vate barroco y el insigne oriolano. Desde la edad temprana de Miguel Hernández, el lúcido análisis de Balcells va iluminando el cómo y el qué de su particular asimilación quevedesca. Un ejemplo es el rol de Ramón Sijé en las lecturas primeras de Miguel Hernández. Uno de los tópicos, por cierto, que arranca públicamente con la dedicatoria de la Elegía a la muerte del amigo. Ya en Miguel Hernández, corazón desmesurado, Balcells apreciaba la importancia de los gustos de Sijé en la poesía hernandiana: “El barroco que atisbaba Sijé venía marcado, como se dijo, por una exigencia epocal. Pero no se aplicó a una mera justificación del formalismo sin alma. Era casi una concepción del mundo. Hernández concordaría probablemente con las intuiciones de su agudo mentor en los primeros años de su despertar a las inquietudes intelectuales." Ese probablemente -por nosotros subrayado- está más que demostrado en el presente artículo. Según Balcells, "del quevedismo poético hernandiano no le cabría apenas participación a Sijé, pero sí le cabría parte en el acercamiento a Quevedo o, más exactamente, al ideario de don Francisco. (...) La inicial aproximación de Miguel Hernández a Quevedo fue inducida por Sijé, cuyos vínculos quevedianos son incontrastables." Vida y obra quedan imbricadas de forma significativa, atendiendo a los códigos textuales primordialmente. Sijé, Neruda, Cossío, los estímulos de acercamiento a Quevedo por parte del poeta, son cuidadosamente analizados.

El rayo que no cesa, Viento del pueblo, Cancionero y romancero de ausencias, poemarios fundamentales, son contemplados a la luz del estoicismo quevedesco, de la poesía del magistral autor barroco, en suma. Tras el revelador capítulo sobre las influencias quevedescas, se hallan dos que se adentran en El rayo que no cesa. El primero, proveniente de la "Introducción" al conjunto, editado por Sial en 2002, y el otro, de título elocuente, "El rayo que no cesa desde la intertextualidad". En cuanto al primero, podríamos definirlo como una auténtica "introducción crítica", en el sentido etimológico de intro ducere, es decir como un viaje hacia el interior del texto, de la mano del rigor filológico. Apasionante deviene la reconstrucción interna de El rayo 
que no cesa, partiendo de las versiones contrastadas en el tiempo de El silbo vulnerado. Reseñables son también las páginas dedicadas a la "Elegía" o las indagaciones sobre la herencia de Petrarca. En efecto, a nadie debe sorprenderle la siguiente afirmación de Balcells: “(...) El rayo que no cesa congrega indicios suficientes y significativos como para que la obra pueda ser calificada de cancionero petrarquista."

Este capítulo se completa con el ya mencionado "El rayo que no cesa desde la intertextualidad". Puede ser el capítulo más logrado de todo el libro. Un poeta a priori tan leído como Miguel Hernández, parece que sea más aprehensible que otros, más sabido. Este trabajo, sobre uno de los conjuntos poéticos cumbre del poeta alicantino, muestra la riqueza y la complejidad nada aparente de la singular voz hernandiana. Mediante el análisis de la intertextualidad, Balcells rescata los ecos, la urdimbre referencial de las diferentes voces que, ora de forma consciente ora inconsciente, han ido tejiendo estructuras, palabras, temas. En palabras de Antonio Machado, "Toda poesía es, en cierto modo, un palimpsesto". Como si de un poeta renacentista se tratase, Balcells rastrea las voces y los ecos de diferente filiación. Desde Garcilaso, San Juan de la Cruz y Góngora hasta Rosalía de Castro, Aleixandre, Bergamín, Neruda, Juan Ramón Jiménez o José María de Cossío. Lo antiguo y lo más absolutamente coétaneo al autor convive en El rayo que no cesa.

Por último, Balcells ha incluido tres trabajos, que nos place denominar personales. "De Josefina a María, y de María a Maruja (Sobre la musa de "Me llamo barro...") apunta a la convivencia de varias amadas junto a la fundamental de Josefina Manresa. La tesis de una única amada para El rayo que no cesa es desmentida por el crítico. Que Miguel Hernández tuviese otras musas, como María Cegarra o la pintora Maruja Mallo, es compatible, como lo fue para Garcilaso de la Vega, con un canzionere petrarquista. Los otros dos ensayos abordan aspectos de la biografía y la poesía hernandiana: la guerra y el trabajo. Son "La sátira de guerra" y "El trabajo: una perspectiva poética", respectivamente. Ambos artículos recaban en aspectos de la poética hernandiana, que no por intuidos son bien conocidos generalmente. Las particularidades de algunos textos de Viento del pueblo y El hombre acecha abocan al mito humano del poeta. La escatología necesaria o la visión hernandiana del trabajo son contempladas por Balcells desde una perspectiva estética de la recepción textual. Los condicionantes políticos, humanos e históricos, en que se concibieron los textos ahora analizados, obligan, en cierta manera, a un tratamiento contextualizador. Esclarecedoras, por ejemplo, devienen las contrastadas comparaciones entre los romances de guerra hernandianos y los de Rafael Alberti. El resultado final es brillante y, ante todo, de gran originalidad en el enfoque. Sirva esta frase, en definitiva, para definir la esencia de un libro, éste de Sujetado rayo. Estudios sobre Miguel Hernández, indispensable para internarse en una de las voces poéticas más logradas del siglo $X X$. 
Juan Carlos Merchán Ruiz 